\title{
NOTA/NOTE
}

\section{Respuesta a corto plazo de parámetros fisicoquímicos del agua a la rehabilitación hidrológica de caños en manglares de Cispata, Caribe colombiano}

\section{Short-term response of water physicochemical parameters to the hydrological rehabilitation of channels in mangroves from Cispata, Colombian Caribbean}

\author{
Ostin Garcés-Ordóñez ${ }^{1,2,3}$ *, Jenny Alexandra Rodríguez-Rodríguez ${ }^{1}$, Luisa Espinosa Díaz ${ }^{1,3}$, \\ $\begin{array}{lll}\text { (iD) } 0000-0001-7942-0371 & \text { (iD) } 0000-0001-8082-8374 & \text { (iD } 0000-0003-1452-3104\end{array}$
}

Fabián Escobar Toledo ${ }^{1}$ y Denise Delvalle Borrero ${ }^{4}$

(iD) $0000-0003-2479-6755 \quad$ (iD) $0000-0002-7696-9710$

1. Instituto de Investigaciones Marinas y Costeras “José Benito Vives de Andréis”-Invemar. Santa Marta, Colombia.ostin.garces@invemar.org.co*;
alexandra.rodriguez@invemar.org.co; luisa.espinosa@invemar.org.co; fabian.escobar@invemarorg.co
2. Universidad Jorge Tadeo Lozano, Programa de Maestría en Gestión Ambiental de Sistemas Marinos y Costeros. Santa Marta, Colombia.
3. Red de Vigilancia para la Conservación y Protección de las Aguas Marinas y Costeras de Colombia-REDCAM, Santa Marta, Colombia.
4. Universidad Tecnológica de Panamá, Centro de Investigaciones Hidráulicas e Hidrotécnicas. Ciudad de Panamá, Panamá. denise.borrero@utp.ac.pa
* Autor de correspondencia

RESUMEN

$\mathrm{S}$ e evaluó la respuesta en el corto plazo ( $<$ seis meses) de parámetros fisicoquímicos del agua a la rehabilitación hidrológica $(\mathrm{RH})$ de caños colmatados en manglares de Cispata, Caribe colombiano. Entre septiembre 2018 y septiembre 2019 se midieron parámetros fisicoquímicos antes y después de la RH. Se calculó el Í́ndice de Calidad de Aguas Marinas y Costeras ( $\left.\mathrm{ICAM}_{\mathrm{PFF}}\right)$ en caños y ciénagas. La calidad del agua antes de la RH en algunas estaciones era pésima, en otras inadecuada y aceptable; después de cinco meses de la RH, la calidad fue aceptable en todas las estaciones. Después de la RH la salinidad y temperatura del agua dentro del manglar disminuyeron a valores adecuados para las plántulas de mangles. En el corto plazo, la RH mejoró significativamente las condiciones fisicoquímicas del agua en caños, ciénagas y dentro del manglar para la preservación de fauna y plántulas de mangles. Los resultados son aplicables en la gestión de la restauración de manglares y su manejo adaptativo.

PALABRAS CLAVE: rehabilitación de manglar, calidad del agua, regeneración natural, indicadores de restauración.

\section{ABSTRACT}

$\mathrm{T}$ he present study evaluated the short-term response (<six months), of water physicochemical parameters to hydrological rehabilitation (HR) of clogged channels in mangrove of Cispata, Colombian Caribbean. Between September 2018 and September 2019, we measure the water physicochemical parameters before and after the HR. The index of marine and coastal water quality $\left(\mathrm{ICAM}_{\mathrm{PFF}}\right)$ in channels and swamps was calculated. Before the HR, in some stations, water quality was very poor, in other inadequate, and in other acceptable; after five months of HR in all stations, water quality became acceptable. After HR, the salinity and temperature of the water within the mangrove decreased to adequate values for the mangrove seedlings. In the short term, HR significantly improved the physicochemical conditions of the water required for the preservation of fauna and seedlings in the channels, swamps, and within the mangrove forest. Our findings are applicable in the mangrove restoration management and their adaptive handling.

KEYWORDS: mangrove rehabilitation, water quality, natural regeneration, restoration indicators.

DOI: https://doi.org/10.25268/bimc.invemar.2021.50.2.1106 
La rehabilitación hidrológica $(\mathrm{RH})$ es una técnica de la restauración ecológica que busca reparar los procesos y la funcionalidad de la hidrología en ecosistemas donde su alteración ha causado la degradación (Lewis, 2005). Esta técnica se ha implementado en manglares centroamericanos y colombianos (Sánchez-Páez et al., 2004; Teutli y Herrera, 2016).

El Distrito de Manejo Integrado Cispata (DMI Cispata) es un área protegida de $\sim 27171$ ha del Caribe colombiano, donde algunas áreas del manglar, como el sector Dago-Ustria (Figura 1), se han deteriorado por la colmatación de caños, interrupción de flujos hídricos y salitrales, que afectan la calidad del agua (CVS e Invemar, 2010; Invemar, 2017). En 2019, instituciones ambientales
Hydrological rehabilitation (HR) is an ecological restoration technique that aims to repair the processes and functionality of hydrology in ecosystems where its alteration has caused degradation (Lewis, 2005). Different authors have implemented this technique in Central American and Colombian mangroves (Sánchez-Páez et al., 2004; Teutli and Herrera, 2016).

The Cispata Integrated Management District (DMI Cispata) is a protected area of $\sim 27171$ ha on the Colombian Caribbean coast, where some mangrove areas, such as the Dago-Ustria sector (Figure 1), have deteriorated due to the clogging of channels, interruption of water flows, and salt crust formation, which affect water quality (CVS and Invemar, 2010; Invemar, 2017). In 2019, environmental

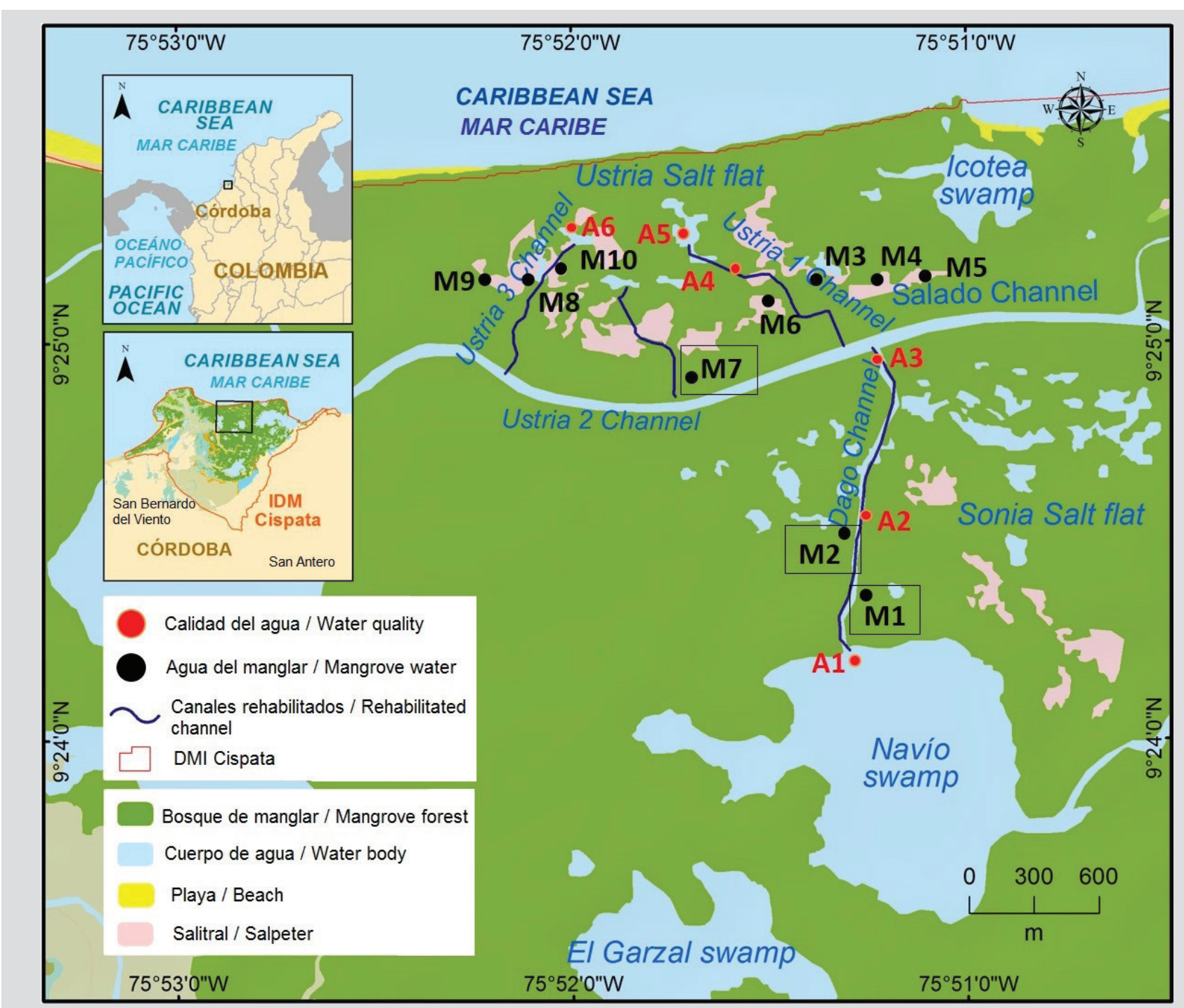

Figura 1. Área de estudio. Puntos rojos (A1-A6) y negros (M1-M10): estaciones de calidad del agua en caños-ciénagas y dentro manglar. Figure 1. Study area. Red (A1-A6) and black (M1-M10) points are the water quality stations in channels and swamps and within mangroves. Estaciones M1, M2 y M7: en manglares conservados (referencia). Stations M1, M2, and M7 are in preserved mangroves used as a reference. 
y la comunidad local rehabilitaron $3267 \mathrm{~m}$ de caños colmatados/taponados para restablecer la conectividad hidrológica (Invemar, 2017).

El objetivo de este estudio fue evaluar las respuestas en el corto plazo ( $<$ seis meses) de parámetros fisicoquímicos del agua en los caños rehabilitados y dentro del manglar en el sector Dago-Ustria. El manglar del sector Dago está conformado por Rhizophora mangle, Avicennia germinans y Laguncularia racemosa (Rojas-Aguirre et al., 2018). El clima es tropical lluvioso de sabana con invierno seco; los promedios multianuales (1981-2010) de precipitación oscilan entre 1000-1500 mm (mayores precipitaciones en mayo y septiembre), de temperatura entre $26-28{ }^{\circ} \mathrm{C}$, de humedad relativa entre $80-85 \%$ y de evapotranspiración entre 1200-1400 mm (IDEAM, 2014a, 2014b).

La dinámica hidrológica está modulada por los caudales del río Sinú (regulados desde 1999 por la Hidroeléctrica Urrá I), las épocas lluviosas y la acción del mar Caribe (Ruíz-Ochoa et al., 2008). Históricamente, el río Sinú ha formado los deltas Venados (antes de 1762), Mestizos (1762-1849), Cispata (1849-1938) y Tinajones (1938-actual) (Serrano, 2004; Ramos et al., 2015). En el DMI Cispata se presentan aguas bajas (enero-mayo) y aguas altas (junio-diciembre) con el descenso o aumento del caudal del río Sinú respecto al promedio anual $\left(389 \mathrm{~m}^{3} / \mathrm{S}\right)$, con un desfase de uno o dos meses de las épocas secas y lluviosas (Ramos et al., 2015).

Considerando lo anterior, los muestreos se realizaron en septiembre 2018 (antes de la RH, época lluviosa), marzo 2019 (antes de la RH, época seca), junio 2019 (después de dos meses de la RH, época seca) y septiembre 2019 (después de cinco meses de la RH, época lluviosa). Desde agosto 2018 a julio 2019 se presentaron condiciones Niño y desde agosto a diciembre de 2019 condiciones normales (NOAA, 2020).

En abril 2019, se realizó la RH de los caños Dago (1500 m), Ustria-1 (602 m), Ustria-2 (700 m) y Ustria-3 (465 m; Figura 1), usando machetes, hachas y palas, removiendo el material vegetal y el sedimento hasta $1 \mathrm{~m}$ de profundidad y mínimo $1 \mathrm{~m}$ de ancho (Figura 2). En los caños Ustria-1 y Ustria-3 se realizaron aperturas de dos canales secundarios de $40 \mathrm{~m}$ de largo, $50 \mathrm{~cm}$ de profundidad y $1 \mathrm{~m}$ de ancho, para la entrada de agua a los salitrales (Figura 1).

Para evaluar la calidad del agua en caños y ciénagas se establecieron seis estaciones de muestreo (A1-A6; Figura 1). Se midieron in situ la temperatura, institutions and the local community rehabilitated $3267 \mathrm{~m}$ of clogged/plugged channels to restore hydrological connectivity (Invemar, 2017).

The objective of this study was to evaluate the short-term responses $(<$ six months) of the water physicochemical parameters in the rehabilitated channels and within the mangrove forests in the Dago-Ustria sector. Species Rhizophora mangle, Avicennia germinans, and Laguncularia racemosa make up the mangrove forest in Dago sector (Rojas-Aguirre et al., 2018). The climate is tropical rainy savanna with a dry season; multiannual averages (1981-2010) of precipitation range between 1000-1500 mm (heavier rainfall in May and September), temperature between $26-28{ }^{\circ} \mathrm{C}$, relative humidity between 80-85\%, and evapotranspiration between 1200-1400 mm (IDEAM, 2014a, 2014b).

The hydrological dynamics are modulated by the flows of the Sinú River (regulated since 1999 by Urrá I hydroelectric dam), the rainy seasons and the action of the Caribbean Sea (Ruíz-Ochoa et al., 2008). Historically, the Sinú River has formed the deltas Venados (before 1762), Mestizos (1762-1849), Cispata (1849-1938), and Tinajones (1938-present) (Serrano, 2004; Ramos et al., 2015). In the DMI Cispata, low waters (January-May) and high waters (June-December) correspond to a decrease or increase in the flow of the Sinú River with respect to the annual average $\left(389 \mathrm{~m}^{3} / \mathrm{S}\right)$, lagging by one or two months from the dry and rainy seasons (Ramos et al., 2015).

Considering the above, the samplings were carried out in September 2018 (before HR, rainy season), March 2019 (before HR, dry season), June 2019 (after two months of HR, dry season), and September 2019 (after five months of HR, rainy season). From August 2018 to July 2019, Niño conditions were present, the condition were normal from August to December 2019 (NOAA, 2020).

In April 2019, the HR of the Dago (1500 m), Ustria-1 (602 m), Ustria-2 (700 m), and Ustria-3 (465 m) channels were carried out (Figure 1), using machetes, axes, and shovels removing plant material and sediment up to $1 \mathrm{~m}$ deep and at least $1 \mathrm{~m}$ wide (Figure 2). In the Ustria-1 and Ustria-3 channels, we made two secondary channels of $40 \mathrm{~m}$ long, $50 \mathrm{~cm}$ deep, and $1 \mathrm{~m}$ wide, to enable water to flow into the salt planes (Figure 1).

To evaluate the water quality in channels and swamps, we established six sampling stations (A1-A6; Figure 1). We measure in situ temperature, salinity, $\mathrm{pH}$, 


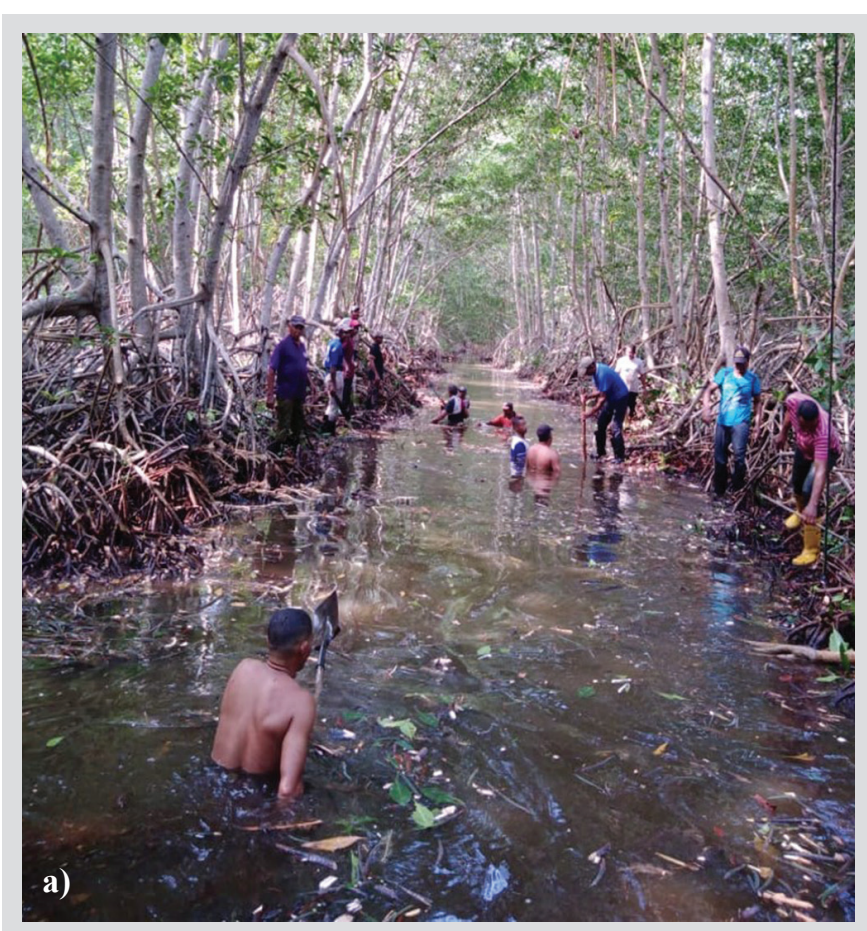

Figura 2. Rehabilitación de los Caños Dago a) y Ustria 1 b) en el DMI Cispata. Fotos: ASOMAPESCA e Invemar.

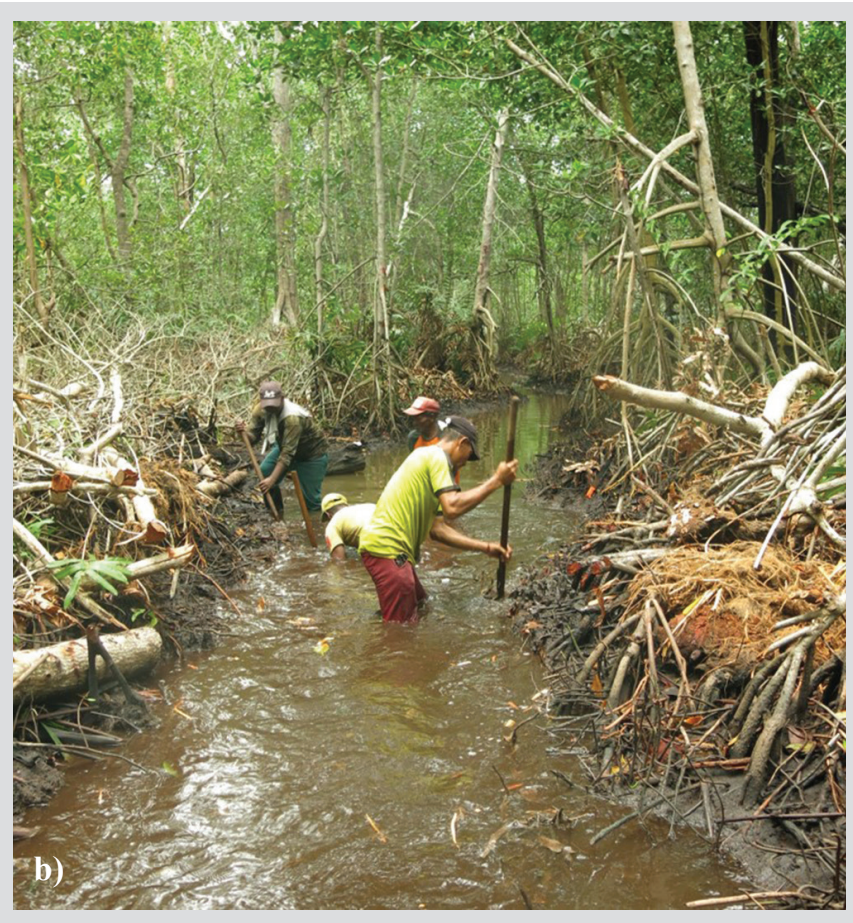

Figure 2. Rehabilitation of the Dago a) and Ustria-1 b) channels in the DMI Cispata. Photos: ASOMAPESCA and Invemar. salinidad, pH y oxígeno disuelto (OD) del agua superficial, tres veces en cada estación, usando un multiparámetro HACH. Además, se recolectó una muestra de agua a 30 $\mathrm{cm}$ de profundidad, con testigo de campo, blanco viajero y réplicas, para medir los parámetros descritos en la Tabla 1. Antes de la RH en época lluviosa, no fue posible realizar las mediciones en la estación A6.

Tabla 1. Métodos de laboratorio utilizados para el análisis de parámetros de calidad de agua. and dissolved oxygen (DO) of the surface water, three times at each station, using a $\mathrm{HACH}$ multiparameter. Additionally, we collected a water sample at a depth of $30 \mathrm{~cm}$, with field control, traveling control sample, and replicas, to measure the parameters described in Table 1. Before HR in the rainy season, we were unable to perform measurements at station A6.

Table 1. Laboratory methods used for the analysis of water

\begin{tabular}{|c|c|c|}
\hline Parámetros / Parameters & $\begin{array}{l}\text { Unidad de medida / } \\
\text { Measurement unit }\end{array}$ & Métodos de Análisis / Analysis methods \\
\hline Nitratos / Nitrates & $\mu \mathrm{g} \mathrm{N}-\mathrm{NO}_{3} / \mathrm{L}$ & $\begin{array}{l}\text { Método colorimétrico, reducción con cadmio / Colorimetric method, reduction } \\
\text { with cadmium (Strickland and Parsons, 1972). }\end{array}$ \\
\hline Ortofosfatos / Orthophosphates & $\mu \mathrm{g} \mathrm{P}-\mathrm{PO}_{4}^{-3} / \mathrm{L}$ & $\begin{array}{l}\text { Método colorimétrico del ácido ascórbico / Ascorbic acid colorimetric method } \\
\text { (Strickland and Parsons, 1972). }\end{array}$ \\
\hline Clorofila $a$ / Chlorophyll $a$ & $\mu \mathrm{g}$ Chla/L & $\begin{array}{l}\text { Filtración en membrana de fibra de vidrio Whatman GF/F (tamaño de } \\
\text { poro } 0.7 \boldsymbol{\mu m} \text { ), secado a } 20{ }^{\circ} \mathbf{C} \text {, extracción con acetona al } \mathbf{9 0} \% \text { y medición } \\
\text { en espectrofotómetro / Filtration on a Whatman } \mathrm{GF} / \mathrm{F} \text { glass fiber membrane } \\
\left(0.7 \mu \mathrm{m} \text { pore size), drying at } 20{ }^{\circ} \mathrm{C} \text {, extraction with } 90 \% \text { acetone and }\right. \\
\text { measurement in a spectrophotometer (APHA et al., 2017). }\end{array}$ \\
\hline $\begin{array}{l}\text { Sólidos suspendidos totales-SST / } \\
\text { Total Suspended Solids-TSS }\end{array}$ & $\mathrm{mg} \mathrm{SST/L}$ & $\begin{array}{l}\text { Filtración en membrana de fibra de vidrio de } \mathbf{4 7} \mathbf{~ m m} \text { (tamaño de poro }<\mathbf{1 , 2} \\
\boldsymbol{\mu m}) \text { previamente tratadas y pesadas, secado } \mathbf{1 0 3}-\mathbf{- 1 0 5}{ }^{\circ} \mathbf{C} \text { y gravimetría } \\
\text { / Filtration on a } 47 \mathrm{~mm} \text { glass fiber membrane }(<1.2 \mu \mathrm{m} \text { pore size) previously } \\
\text { treated and weighed, drying } 103-105^{\circ} \mathrm{C} \text { and gravimetry (APHA et al., 2017). }\end{array}$ \\
\hline $\begin{array}{l}\text { Demanda bioquímica de oxígeno- }-\mathrm{DBO}_{5} / \\
\text { Biochemical oxygen demand- } \mathrm{BOD}_{5}\end{array}$ & $\mathrm{mg} \mathrm{O}_{2} / \mathrm{L}$ & $\begin{array}{l}\text { Incubación sin dilución durante } 5 \text { días a } 20^{\circ} \mathbf{C} \text { / Incubation without dilution } \\
\text { for } 5 \text { days at } 20^{\circ} \mathrm{C} \text { (Garay et al., 2003). }\end{array}$ \\
\hline
\end{tabular}


Dentro del manglar se seleccionaron diez estaciones (M1-M10; Figura 1), de las cuales M1-M2 y M7 se ubicaron en el manglar conservado como referencia. Las estaciones M3-M6, M8-M10 se ubicaron en el manglar degradado por salitrales. En cada estación se midieron en tres puntos la salinidad, temperatura y $\mathrm{pH}$ en el agua superficial e intersticial (profundidad: $0,5 \mathrm{~m}$ ), usando el multiparámetro $\mathrm{HACH}$ y el nivel del agua utilizando una regla. Para obtener las muestras de agua intersticial se utilizó la metodología de Invemar (2018a). En la estación M7 no fue posible realizar las mediciones antes de la RH en época lluviosa.

Los resultados se compararon con los criterios nacionales de preservación de flora y fauna en aguas estuarinas (MinAmbiente, 2015) y con valores de referencia. Se calculó el Índice de Calidad de Aguas Marinas y Costeras para la Preservación de Flora y Fauna $\left(\mathrm{ICAM}_{\mathrm{PFF}}\right)$ en caños y ciénagas, con los datos de $\mathrm{OD}, \mathrm{pH}$, nitratos, ortofosfatos, SST, clorofila $a$ y $\mathrm{DBO}_{5}$ (Invemar, 2018b), y un margen de confianza de $86 \%$. El ICAM $\mathrm{PFF}_{\mathrm{PF}}$ califica la calidad del agua en óptima, adecuada, aceptable, inadecuada y pésima (Invemar, 2018b). Se determinaron las diferencias significativas entre los cuatro muestreos realizados antes y después de la RH con la prueba de Kruskal-Wallis, en InfoStat ${ }^{\circledR}$ profesional versión 2016, con un intervalo de confianza de $95 \%$.

En el agua superficial de caños y ciénagas disminuyeron los valores de temperatura, salinidad y $\mathrm{pH}$ después de la RH (Figura 3a-c), presentando diferencias significativas entre los muestreos antes y después de la RH (Temperatura: $\mathrm{P}=0,006$; Salinidad: $\mathrm{P}=0,004 ; \mathrm{pH}$, $\mathrm{P}=0,011)$. El OD aumentó ligeramente después de la RH en algunas estaciones (Figura 3d), sin presentar diferencias significativas. $\mathrm{La} \mathrm{DBO}_{5}$, nitratos y nitritos aumentaron y los SST disminuyeron después de la RH (Figura 3e-h), mostrando diferencias significativas antes y después de la RH $\left(\mathrm{DBO}_{5}\right.$ : $\mathrm{P}=0,006$; SST: $\mathrm{P}=0,005$; nutrientes: $\mathrm{P}=0,001)$. La concentración de clorofila $a$ no presentó diferencias significativas.

El ICAM $_{\mathrm{PFF}}$ mostró que antes de la RH en época de lluvias, la calidad del agua fue pésima e inadecuada en las estaciones A2 y A6 respectivamente, y aceptable en las demás estaciones; y en la época seca, la calidad fue inadecuada en las estaciones A4-A6 y aceptable en las estaciones A1-A3 (Figura 4). Después de dos meses de la $\mathrm{RH}$, la calidad del agua mejoró en todas las estaciones, con excepción de A1 y A4; y después de cinco meses la calidad fue aceptable en todas las estaciones (Figura 4). quality parameters.

We selected ten stations within the mangrove forest (M1-M10; Figure 1), of which M1-M2 and M7 were located in the preserved mangrove as reference stations. Stations M3-M6, M8-M10 were located in the mangrove forest degraded by the salt crust formation. At each station, the salinity, temperature, and $\mathrm{pH}$ in the surface and interstitial waters (depth: $0.5 \mathrm{~m}$ ) were measured at three points, using the $\mathrm{HACH}$ multiparameter, and the water level was determined using a ruler. We use the methodology Invemar (2018a) to obtain the interstitial water samples. At station M7, it was not possible to perform measurements before HR in the rainy season.

We compared our results with the national criteria for flora and fauna preservation in estuarine waters (MinAmbiente, 2015) and with reference values. The Index of Marine and Coastal Waters Quality for Flora and Fauna Preservation $\left(\mathrm{ICAM}_{\mathrm{PFF}}\right)$ was calculated in channels and swamps, with data of $\mathrm{DO}, \mathrm{pH}$, nitrates, orthophosphates, TSS, chlorophyll $a$, and $\mathrm{BOD}_{5}$ (Invemar, 2018b), and with a confidence margin of $86 \%$. The ICAM $\mathrm{IPF}_{\mathrm{PF}}$ qualifies the water quality as optimal, adequate, acceptable, inadequate, and poor (Invemar, 2018b). The significant differences between the four samplings carried out before and after the HR were determined with the Kruskal-Wallis test, in InfoStat ${ }^{\mathbb{E}}$ professional version 2016, with a $95 \%$ confidence interval.

In the surface water of channels and swamps, the values of temperature, salinity, and $\mathrm{pH}$ decreased after the HR (Figure 3a-c), showing significant differences between the samplings before and after the HR (Temperature: $\mathrm{P}=0.006$; Salinity: $\mathrm{P}=0.004 ; \mathrm{pH}, \mathrm{P}=0.011)$. The $\mathrm{DO}$ increased slightly after $\mathrm{HR}$ in some stations (Figure $3 \mathrm{~d}$ ), without significant differences. $\mathrm{BOD}_{5}$, nitrates and nitrites increased and TSS decreased after HR (Figure $3 \mathrm{e}-\mathrm{h}$ ), showing significant differences before and after HR $\left(\mathrm{BOD}_{5}: \mathrm{P}=0.006\right.$; TSS: $\mathrm{P}=0.005$; nutrients: $\mathrm{P}=0.001$ ). The chlorophyll- $a$ concentration did not show significant differences.

The ICAM $\mathrm{PFF}_{\mathrm{PF}}$ showed that before the HR in the rainy season the water quality was poor and inadequate at stations A2 and A6 respectively, and acceptable in the other stations; and in the dry season, the water quality was inadequate at stations A4-A6 and acceptable at stations A1A3 (Figure 4). After two months of the HR, water quality improved at all the stations, except for A1 and A4; and after five months, the water quality was acceptable at all stations (Figure 4). 


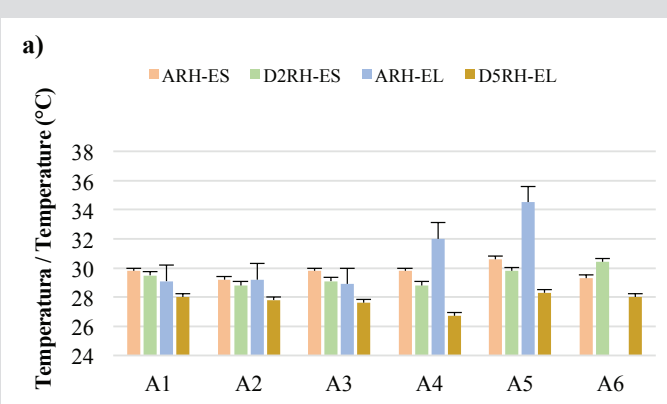

c)

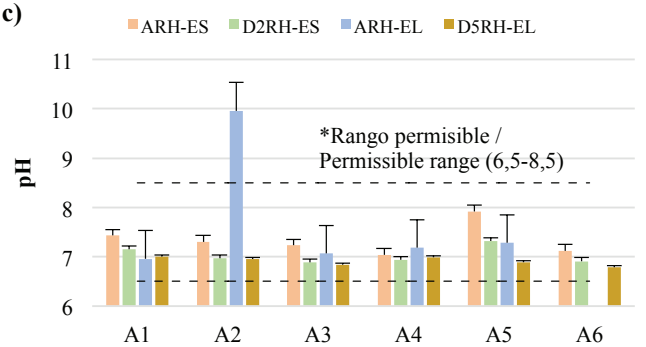

e)

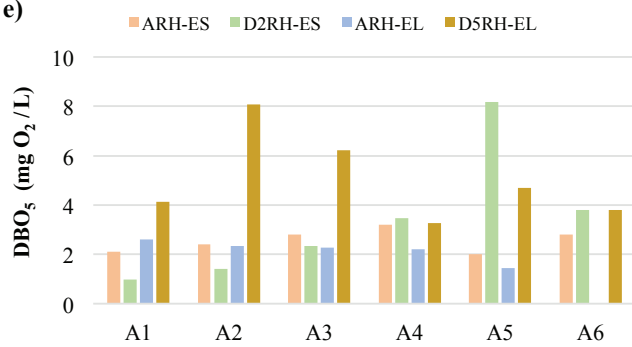

g)

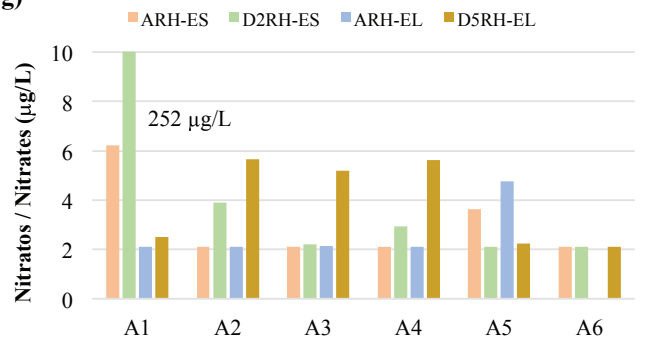

b)

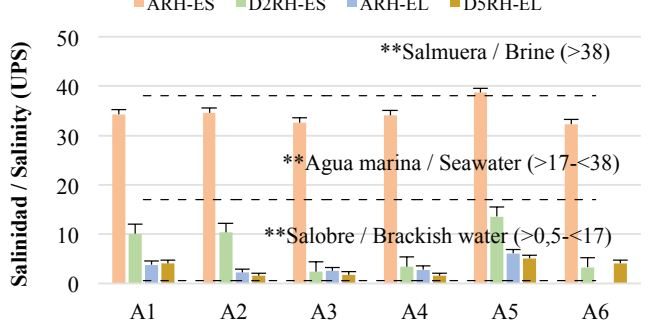

d)

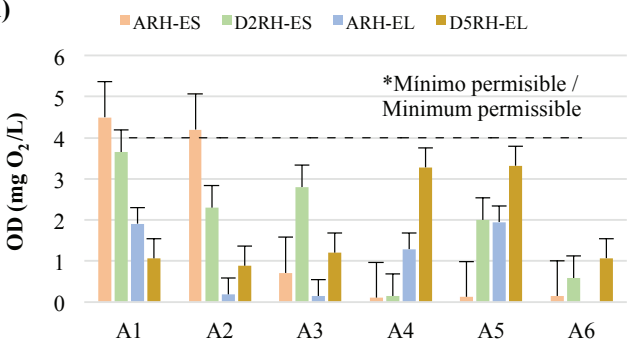

f)

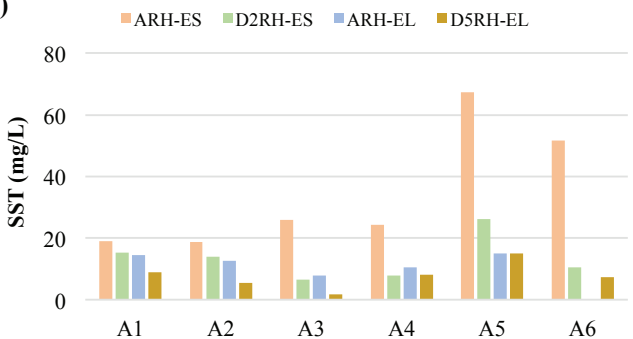

h)

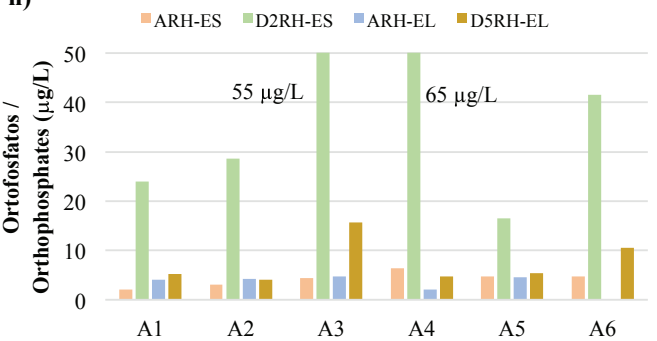

i)

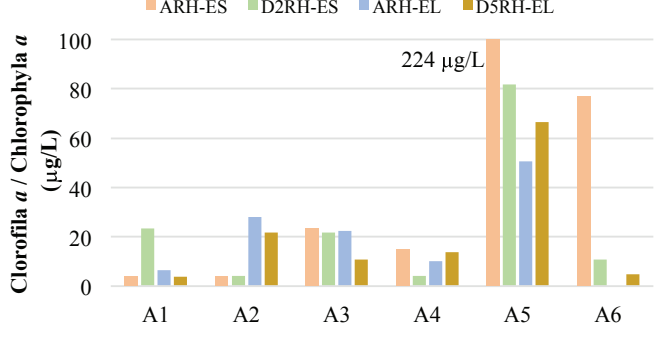

Figura 3. Resultados de los parámetros fisicoquímicos del agua en caños y ciénagas: ARH-ES (antes RH, época seca), D2RH-ES (después de dos meses RH, época seca), ARH-EL (antes RH, época lluviosa) y D5RH-EL (después de cinco meses RH, época lluviosa). **Referencia para clasificación del agua según salinidad (Knox, 2001). *Límites permisibles de la legislación colombiana para la preservación de flora y fauna en aguas estuarinas (MinAmbiente, 2015).
Figure 3. Results of the water physicochemical parameters in channels and swamps: ARH-ES (before HR, dry season), D2RH-ES (after two months of HR, dry season), ARH-EL (before HR, rainy season) and D5RH-EL (after five months of HR, rainy season). ${ }^{* *}$ Reference for water classification according to salinity (Knox, 2001). *Permissible limits of Colombian legislation for flora and fauna preservation in estuarine waters (MinAmbiente, 2015). 

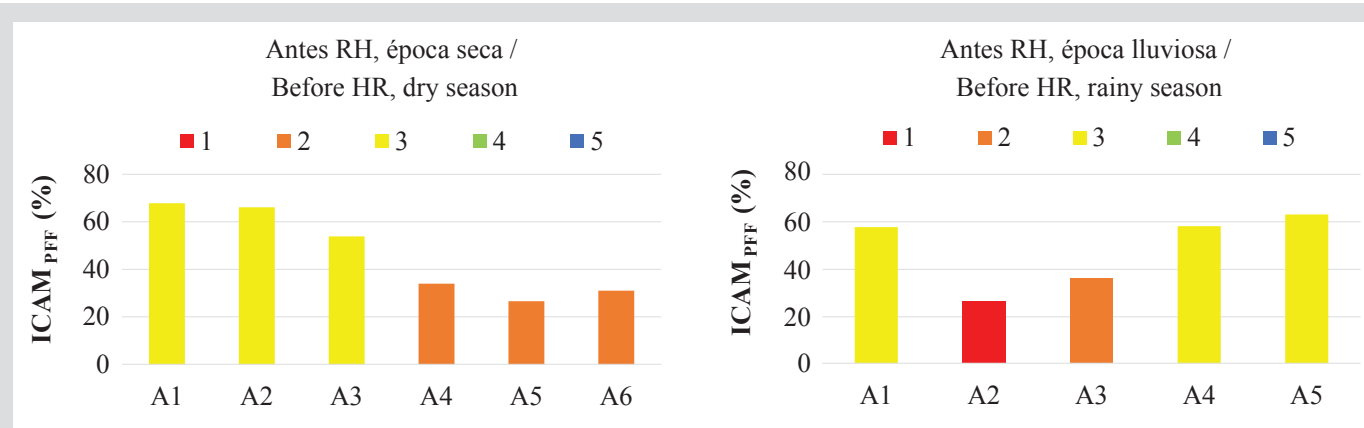

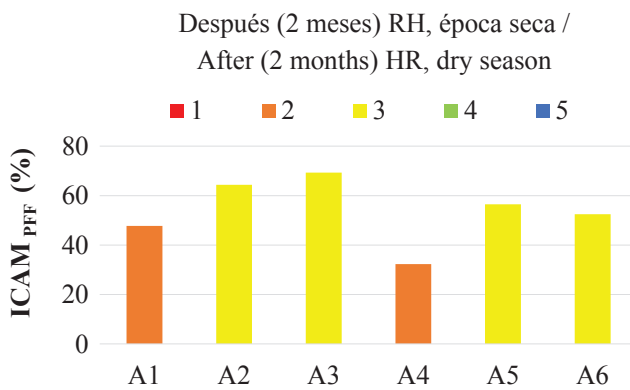

Figura 4. Resultados del ICAM $\mathrm{IPF}_{\mathrm{PF}}$ antes y después de la RH en el sector Dago-Ustria, DMI Cispata. Clasificación de la calidad del agua según el $\mathrm{ICAM}_{\mathrm{PFF}}$ : 1) pésima, 2) inadecuada, 3) aceptable, 4) adecuada y 5) óptima.

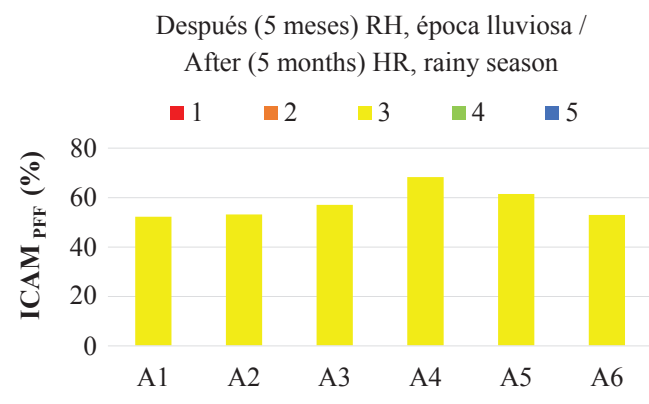

Figure 4. $\mathrm{ICAM}_{\mathrm{PFF}}$ results before and after HR in the Dago-Ustria sector, DMI Cispata. Classification of water quality according to ICAM $_{\mathrm{PFF}}$ : 1) poor, 2) inadequate, 3) acceptable, 4) adequate, and 5) optimal.
Después de la RH aumentó la inundación dentro del manglar (Figura 5a), mostrando diferencias significativas antes y después de la RH $(\mathrm{P}=0,0001)$. Las mayores salinidades, temperatura y $\mathrm{pH}$ se registraron en las estaciones del manglar degradado, las cuales disminuyeron después de la RH (Figura 5b-d), mostrando diferencias significativas antes y después de la RH (Salinidad: $\mathrm{P}=0,0028$; temperatura: $\mathrm{P}=0,0001 ; \mathrm{pH}: \mathrm{P}=0,0005$ ). Entre las estaciones de referencia y las del manglar degradado, la salinidad, temperatura y $\mathrm{pH}$ del agua después de la $\mathrm{RH}$ no fueron significativamente diferentes.

La RH mejoró las condiciones fisicoquímicas del agua en el área de estudio, resultando en condiciones aceptables para la preservación de fauna y mangles. La temporada climática puede acelerar o limitar los cambios en los parámetros fisicoquímicos del agua (Invemar, 2018a); por lo cual, el monitoreo de la calidad del agua a largo plazo es necesario.

La RH permitió el ingreso de agua dulce hacia los caños, ciénaga y dentro del manglar de Ustria en la época seca, disminuyendo la salinidad a $<10$. Esta salinidad es característica de aguas salobres oligohalinas $(>0,6-10$; Knox, 2001), óptima para el crecimiento de las plántulas (3-27; Krauss et al., 2008). Asimismo, la temperatura
After the HR, flooding within the mangrove forest increased (Figure 5a), showing significant differences before and after the HR $(\mathrm{P}=0.0001)$. The highest salinities, temperature, and $\mathrm{pH}$ were recorded at the degraded mangrove stations, which decreased after HR (Figure 5b-d), showing significant differences before and after HR (Salinity: $\mathrm{P}=0.0028$; temperature: $\mathrm{P}=0.0001$; $\mathrm{pH}$ : $\mathrm{P}=0.0005)$. Between the reference stations and those of the degraded mangrove, salinity, temperature, and $\mathrm{pH}$ of the water after the HR were not significantly different.

The HR improved the physicochemical conditions of the water in the study area, resulting in acceptable conditions for the preservation of fauna and mangrove plants. The climatic season can accelerate or limit the changes in the water physicochemical parameters (Invemar, 2018a); therefore, long-term water quality monitoring is necessary.

The HR allowed freshwater to enter the channels, swamp, and within the mangrove forest of the Ustria sector in the dry season, reducing salinity to $<10$. This salinity is characteristic of oligohaline brackish waters $(>0.6-10$; Knox, 2001) and is optimal for seedling growth (3-27; Krauss et al., 2008). Likewise, the temperature of the surface water decreased. At the M3 station, $43{ }^{\circ} \mathrm{C}$ were recorded in the 

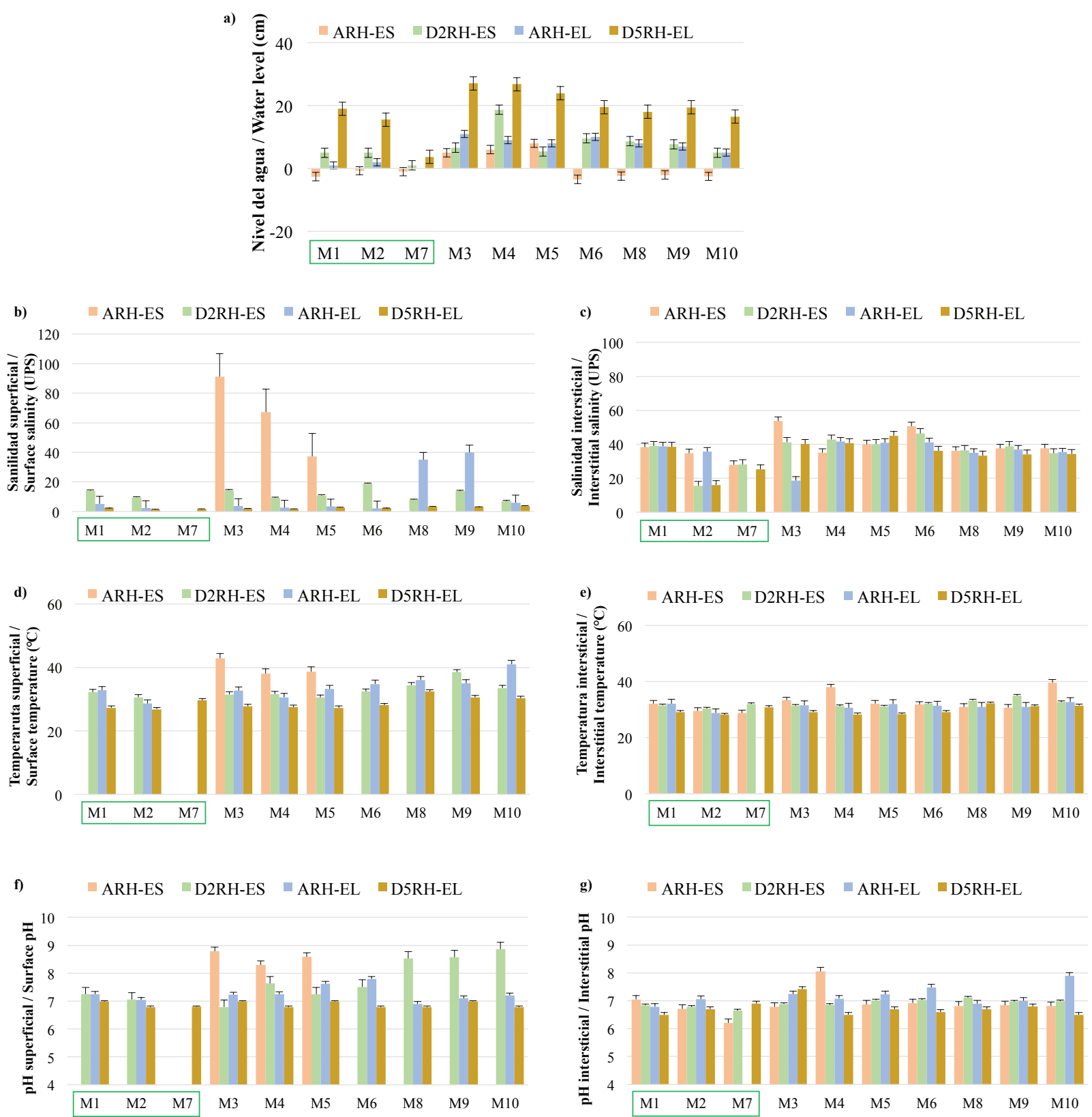

Figura 5. Resultados de los parámetros fisicoquímicos del agua dentro del manglar. Muestreos: ARH-ES (antes de la RH, época seca), D2RHES (después de dos meses de la RH, época seca), ARH-EL (antes de la RH, época lluviosa) y D5RH-EL (después de cinco meses de la RH, época lluviosa). Los recuadros verdes señalan las parcelas de referencia (M1, M2 y M7).
Figure 5. Results of the physicochemical parameters of the water within the mangrove forest. Sampling: ARH-ES (before HR, dry season), D2RH-ES (after two months of HR, dry season), ARH-EL (before HR, rainy season), and D5RH-EL (after five months of HR, rainy season). The green boxes indicate the reference plots (M1, M2, and M7). del agua superficial disminuyó. En la estación M3 se registraron $43{ }^{\circ} \mathrm{C}$ en el agua superficial antes de la $\mathrm{RH}$, la cual supera $35{ }^{\circ} \mathrm{C}$ y puede afectar el crecimiento de propágulos (Febles et al., 2007), además provocar lesiones necróticas en las hojas al superar $40^{\circ} \mathrm{C}$ (Krauss et al., 2008) e influir sobre otros parámetros fisicoquímicos relacionados con la nutrición (Reef et al., 2010). Después de la RH la surface water before the $\mathrm{HR}$, which exceeds $35^{\circ} \mathrm{C}$ and can affect the growth of propagules (Febles et al., 2007), besides causing necrotic lesions on the leaves by overcoming $40{ }^{\circ} \mathrm{C}$ (Krauss et al., 2008) and influencing other physicochemical parameters related to nutrition (Reef et al., 2010). After HR, the water temperature ranged between $28-32{ }^{\circ} \mathrm{C}$, adequate for the growth of mangrove seedlings (Krauss et al., 2008). 
temperatura del agua osciló entre $28-32{ }^{\circ} \mathrm{C}$, adecuada para el crecimiento de las plántulas (Krauss et al., 2008).

El pH del agua en caños y ciénagas estuvo dentro del rango permisible para la preservación de flora y fauna (Figura $3 \mathrm{c}$ ). Dentro del manglar, el $\mathrm{pH}$ del agua fue similar al registrado en las estaciones de referencia, y estuvo dentro del rango típico reportado para manglares del Caribe colombiano (5,08,2; Garcés-Ordóñez y Vivas-Aguas, 2014), que favorecen la disponibilidad de nutrientes esenciales (Reef et al., 2010). El OD en la mayoría de las estaciones fue menor al límite permisible para la preservación de flora y fauna en aguas estuarinas (Figura 3d) y por debajo de $2 \mathrm{mg} \mathrm{O}_{2} / \mathrm{L}$ (condición subóxica), asociado a la $\mathrm{DBO}_{5}$ que aumentó, posiblemente por la remoción de materia orgánica durante la $\mathrm{RH}$.

En conclusión, en el corto plazo, la RH en el sector Dago-Ustria, indujo cambios rápidos en las condiciones fisicoquímicas del agua en caños, ciénagas y dentro del manglar degradado, mejorando la calidad del agua para la preservación de fauna y mangles. Es necesario el monitoreo de la calidad del agua a largo plazo (> cinco años) para evidenciar cambios significativos ajustados a las variaciones ambientales temporales, así como la inclusión y seguimiento de indicadores biológicos (peces y regeneración natural) que respondan a las mejoras de las condiciones del hábitat. Este monitoreo a largo plazo contribuirá con información para el manejo adaptativo de la restauración de manglares en el DMI Cispata y de otras áreas en Colombia.

\section{AGRADECIMIENTOS}

Este trabajo hace parte de la Acción MAPCO, cofinanciada por la Unión Europea, Invemar y Fundación Natura. Gracias al Invemar y a la Universidad Jorge Tadeo Lozano por el soporte institucional, al investigador Felipe Valencia por el apoyo cartográfico y a la comunidad de San Antero por el apoyo en los trabajos de campo. Contribución científica del Invemar No. 1299.
The $\mathrm{pH}$ of the water in channels and swamps was within the permissible range for flora and fauna preservation (Figure 3c). Within the mangrove forest, the $\mathrm{pH}$ of the water was similar to that registered at the reference stations and was within the typical range reported for mangroves from the Colombian Caribbean (5.0-8.2; Garcés-Ordóñez and Vivas-Aguas, 2014). This $\mathrm{pH}$ favors the availability of essential nutrients (Reef et al., 2010). At most stations, the DO was lower than the permissible limit for flora and fauna preservation in estuarine waters (Figure 3d) and below $2 \mathrm{mg} \mathrm{O}_{2} / \mathrm{L}$ (suboxic condition), associated with the increased $\mathrm{BOD}_{5}$, possibly due to the removal of organic matter during the HR.

In conclusion, in the short term, the HR in the DagoUstria sector induced rapid changes in the physicochemical conditions of the water in the channels, swamps, and within the degraded mangrove forest, improving the water quality for the preservation of fauna and mangrove plants. Longterm water quality monitoring ( $>$ five years) is necessary to show significant changes adjusted to temporary environmental variations. In addition, it is equally necessary to include and monitor of biological indicators (fish and natural regeneration) that respond to improvements in the habitat conditions. This long-term monitoring will yield information for the adaptive management of mangrove restoration in the Cispata DMI and in other mangrove areas of Colombia.

\section{ACKNOWLEDGMENTS}

This work is part of the MAPCO Action, co-financed by the European Union, Invemar, and Natura Foundation. Thanks to Invemar and Universidad Jorge Tadeo Lozano for the institutional support, to the researcher Felipe Valencia for the cartographic support and to the San Antero community for the support in the fieldwork. Scientific contribution of Invemar No. 1299.

\section{BIBLIOGRAFÍA/ LITERATURE CITED}

APHA, AWWA and WEF. 2017. Standard methods for the examination of water and wastewater. 23 rd ed. Am. Public Health Assoc., Am. Water Works Assoc., Water Environ. Fed., Washington. 1400 p.

CVS e Invemar. 2010. Plan integral de manejo del Distrito de Manejo Integrado (DMI) bahía de Cispata - La Balsa - Tinajones y sectores aledaños del delta estuarino del río Sinú, departamento de Córdoba. Rojas, G. X y P. Sierra-Correa (eds.). Serie de Publicaciones Especiales 18 Invemar. 141 p.

Febles, J. L., J. Novelo López y E. Batllori Sampedro. 2007. Efecto de factores abióticos en el desarrollo de raíces primarias, crecimiento y supervivencia de propágulos en Rhizophora mangle. Madera y bosques, 13(2): 15-27. https://dx.doi.org/10.21829/myb.2007.1321226

Garay, J., G. Ramírez, J. M. Betancourt, B. Marín, B. Cadavid, L. Panizzo, L. Lesmes, J. E. Sánchez, S.H. Lozano y A. Franco. 2003. Manual de técnicas analíticas para la determinación de parámetros físicoquímicos y contaminantes marinos: Aguas, sedimentos y organismos. Invemar, Santa Marta. 148 p. 
Garcés-Ordóñez, O. y L.J. Vivas-Aguas. 2014. Calidad del agua en áreas priorizadas de manglar en el Caribe y Pacífico colombianos. Convenio No. 190 de 2014 MADS-Invemar, Santa Marta. 137 p.

IDEAM. 2014a. Clasificaciones climáticas. Inst. Hidrol., Met.. Est. Amb. http://atlas.ideam.gov.co/cclimatologicas/info/clasifclim.html

IDEAM. 2014b. Atlas climatológico de Colombia 1981-2010. Inst. Hidrol., Met. Est. Amb.. http://atlas.ideam.gov.co/visorAtlasClimatologico.html

Invemar. 2017. Plan básico de restauración y monitoreo para 150 ha de manglar en el distrito de manejo integrado de Cispata, Córdoba. Inf. técn. final. Santa Marta, $43 \mathrm{p}$.

Invemar. 2018a. Monitoreo de las condiciones ambientales y los cambios estructurales y funcionales de las comunidades vegetales y de los recursos pesqueros durante la rehabilitación de la Ciénaga Grande de Santa Marta. Inf. Téen. Final 2017. Vol.16. Santa Marta 174 p.+ anexos. http://www. invemar.org.co/inf-cgsm

Invemar. 2018b. Indicador de calidad de aguas marinas y costeras para la preservación de flora y fauna. Disponible desde internet en: http://siam.invemar. org.co/redcam-icam (con acceso el 27/01/2018).

Knox, G.A. 2001. The ecology of seashore. CRC Press, Boca Raton, EE. UU. 557 p.

Krauss, K., C. Lovelock, K. Mckee, L. López-Hoffman, S. Ewe and W. Sousa. 2008. Environmental drivers in mangrove establishment and early development: a review. Aquat. Bot., 89: 105-127. https://doi.org/10.1016/j.aquabot.2007.12.014.

Lewis, R. 2005. Ecological engineering for successful management and restoration of mangrove forests. Ecol. Eng., 24(4): 403-418. https://doi.org/10.1016/j. ecoleng.2004.10.003

MinAmbiente. 2015. Decreto 1076 de 26 de mayo de 2015. Decreto Único Reglamentario del Sector Ambiente y Desarrollo Sostenible. Bogotá, 653 p. https://www.suin-juriscol.gov.co/viewDocument.asp?id=30019960

NOAA. 2020. Historical El Nino / La Nina episodes (1950-present). https:/origin.cpc.ncep.noaa.gov/products/analysis_monitoring/ensostuff/ONI_v5.php

Ramos, L., C. Giraldo, J. Beltran, H. Bustos, H. Castillo, R. Acevedo, C. Ruiz, F. Valencia y J. Bolaño. 2015. Plan de seguimiento y monitoreo de la zona deltaico estuarina del río Sinú (noviembre 2000 - diciembre 2015). Invemar. Inf. Técn. Final, fase XVIII empresa URRÁ S.A. E.S.P., Santa Marta. $388 \mathrm{p}+$ anexos y mapas.

Reef, R., I. Feller and C. Lovelock. 2010. Nutrition of mangroves. Tree Physiol., 30 (9): 1148-1160. https://doi.org/10.1093/treephys/tpq048

Rojas-Aguirre, S., L. Cardona, O. Garcés-Ordóñez y J. Beltran. 2018. Monitoreo ambiental de los manglares de Cispatá, Córdoba, para el fortalecimiento del Sistema de Información para la Gestión de los manglares de Colombia-SIGMA. Informe técnico final convenio 032-2017 CVS-URRÁ S.A. E.S.P. e Invemar. Código PRY-CAM-017-17, Santa Marta. 48 p.

Ruíz-Ochoa, M., G. Bernal y J. Polanía. 2008. Influencia del río Sinú y el mar Caribe en el sistema lagunar de Cispata. Bol. Invest. Mar. Cost., 37(1): 29-49. https://doi.org/10.25268/bimc.invemar.2008.37.1.180

Sánchez-Páez, H., G. Ulloa y H. Tavera. 2004. Manejo integral de los manglares por comunidades locales, Caribe de Colombia. Proyecto PD 60/01 Rev. 1. (F): manejo sostenible y restauración de los manglares por comunidades locales del Caribe de Colombia. MAVDT, CONIF y OIMT. Bogotá. 335 p.

Serrano, B. 2004. The Sinú river delta on the northwestern Caribbean coast of Colombia: Bay infilling associated with delta development. J. SA Earth Sci., 16(7): 623-631. https://doi.org/10.1016/j.jsames.2003.10.005

Strickland, J.D.H. and T.R. Parsons. 1972. A practical handbook of seawater analysis. 2nd Ed. Fish. Res. Board Canada, Ottawa. 328 p. https://epic.awi.de/ id/eprint/39262/1/Strickland-Parsons_1972.pdf

Teutli, C. y J. Herrera-Silveira. 2016. Capitulo 20: Estrategia de restauración de manglares de México: el caso Yucatán. 459-484. En: Ceccon, E. y C. Martínez (Eds.) Experiencias mexicanas en la restauración de los ecosistemas. Prim. Ed. UNAM, UAEM Conabio, Cuernavaca. 577 p. https://www. crim.unam.mx/web/sites/default/files/Experiencias\%20mexicanas.pdf 